\title{
Analisis Efektivitas Antenatal Care (ANC) dan Konsumsi Suplemen Fe-Folat Pada Ibu Hamil di Kecamatan Karangjati
}

\author{
Hanifah Fathimatuzzahrah \\ Prodi Pendidikan Dokter \\ Universitas Sebelas Maret, Surakarta, Indonesia \\ hanifahfathimah@student.uns.ac.id
}

\begin{abstract}
Birth, growth, and development of babies depends on how they survive in the mother's womb. They could survive with sufficient maternal nutrition, such as Fe-Folate. Pregnant women with low food intake or poor quality nutrition intake or both could lead to chronic energy deficiency (CED). Moreover, pregnant women with iron deficiency could cause anemia. Both chronic energy deficiency and anemia could lead to an increase in stunting (low birth weight) rate. WHO recommendation to reduce CED and anemia numbers is by implementing Antenatal Care $(A N C)$ system and Fe-Folate supplement routine distribution to pregnant women in every healthcare services in the world. The objective of this study is to analyze whether ANC and the distribution of Fe-Folate supplement effectively reduce the CED and anemia numbers in Karangjati sub-district, Ngawi. This study was a qualitative method in which researcher interviewed the parties related to the case (The Head of UPT Karangjati), and given the required data (ANC, CED, Anaemia data in UPT Karangjati). The result shows that Antenatal Care (Patteh Paduka Beristri Program) and Fe-Folate supplement routine distribution by UPT Karangjati to pregnant women had effectively reduced CED and anemia numbers in Karangjati sub-district.
\end{abstract}

Keywords: antenatal care, anemia, pregnancy, chronic energy deficiency

\section{PENDAHULUAN}

Ibu hamil merupakan salah satu kelompok masyarakat yang mudah mengalami gangguan kesehatan karena kekurangan gizi (Besuni, 2013). Dikatakan sebagai masa yang rawan kesehatan, yaitu masa kesehatan ibu yang mengandung maupun bayi yang dikandungnya, maka semasa kehamilan perlu dilakukan pemeriksaan secara teratur, hal ini dilakukan guna menghindari gangguan sedini mungkin dari segala sesuatu yang membahayakan terhadap kesehatan ibu dan bayi ${ }^{5}$. Saat ini masih banyak ibu hamil yang mengalami masalah gizi khususnya gizi kurang seperti Kurang Energi Kronik (KEK) dan anemia. Kejadian KEK dan anemia pada ibu hamil biasanya disebabkan karena asupan rendah zat gizi ibu selama kehamilan bukan hanya berdampak pada bayi yang dilahirkan, tetapi juga merupakan factor risiko kematian ibu (Mardiatun, 2015).

Kekurangan energi kronis pada ibu hamil adalah keadaan gizi kurang yang terjadi karena tubuh kekurangan salah satu atau beberapa jenis zat gizi yang dibutuhkan saat kehamilan. Penyebab tubuh kekurangan zat gizi bisa dikarenakan oleh jumlah zat gizi yang dikonsumsi kurang, mutu zat gizi yang rendah atau keduanya. Selain itu, memungkinkan bila zat gizi yang dibutuhkan gagal untuk di serap dan digunakan oleh tubuh. Kenaikan volume darah selama kehamilan akan meningkatkan kebutuhan Fe atau zat Besi (Mardiatun, 2015). Anemia adalah kekurangan zat gizi yang diperlukan untuk sintesis eritrosit, terutama zat-zat seperti zat besi, vitamin B12, asam folat. Selain itu bisa merupakan akibat dari bermacam-macam kondisi seperti pendarahan, kelainan genetik penyakit kronis atau keracunan. Pada kehamilan, tubuh kekurangan beberapa zat gizi maka akan terjadi anemia (Fitri, 2015). Anemia pada ibu hamil adalah masalah kesahatan masyarakat yang paling penting di 
dunia. WHO memperkirakan bahwa lebih dari setengah ibu hamil di dunia memiliki level hemoglobin yang mengindikasikan bahwa ibu hamil tersebut anemia $(<11.0 \mathrm{gl} / \mathrm{dl})$. Prevalensi angka ibu hamil anemia bisa mencapai 56\%-61\% di negara berkembang (Stephen, 2018).

Ibu hamil merasa anemia karena kebutuhan akan zat besi dan vitamin lainnya termasuk asam folat meningkat akibat beban fisiologis ketika kehamilan. Ketidakmampuan ibu hamil untuk memenuhi angka yang diperlukan untuk zat-zat ini baik sebagai akibat dari kekurangan makanan atau infeksi maka akan menimbulkan anemia (Stephen, 2018). Selain itu, kurangnya asupan energi yang berasal dari zat gizi makro (karbohidrat, protein dan lemak) maupun zat gizi mikro terutama vitamin A, vitamin D, asam folat, zat besi, zinc, kalsium dan iodium serta zat gizi mikro lain pada wanita usia subur yang berkelanjutan (remaja sampai masa kehamilan), mengakibatkan terjadinya kurang energi kronik (KEK) pada masa kehamilan, yang diawali dengan kejadian risiko KEK dan ditandai oleh rendahnya cadangan energi dalam jangka waktu cukup lama yang diukur dengan lingkar lengan atas (Kemenkes, 2017).

Anemia selama kehamilan memiliki dampak negatif bagi kesehatan ibu dan anak dan meningkatkan risiko kematian ibu dan perinatal. Dampak negatif kesehatan bagi ibu hamil termasuk kelelahan, kapasitas kerja yang buruk, gangguan fungsi imun tubuh, peningkatan risiko penyakit jantung, dan kematian. Beberapa penelitian menunjukkan anemia selama kehamilan berkontribusi $23 \%$ secara tidak langsung sebagai penyebab kematian ibu hamil di negara berkembang. Anemia pada kehamilan dikaitkan dengan peningkatan risiko kelahiran prematur dan bayi berat lahir rendah (BBLR). Prematur dan BBLR merupakan penyebab utama kematian neonatal di Indonesia, negara berkembang keseluruhan berkontribusi hingga 30\% dari total kematian tersebut. Angka tersebut juga telah dikaitkan dengan peningkatan risiko intrauterine fetal death (IUFD), skor APGAR (metode cepat untuk merangkum kesehatan bayi baru lahir terhadap kematian bayi) rendah pada 5 menit pertama, dan intrauterine growth restriction (IUGR) yang merupakan risiko stunting di antara anakanak kurang dari dua tahun (Stephen, 2018). Kondisi ibu hamil KEK berisiko tinggi menurunkan kekuatan otot ibu yang bekerja saat proses persalinan sehingga dapat mengakibatkan terjadinya kematian janin (keguguran), prematur, lahir cacat, bayi berat lahir rendah (BBLR) bahkan kematian bayi, ibu hamil KEK dapat mengganggu tumbuh kembang janin yaitu pertumbuhan fisik (stunting), otak dan metabolisme yang menyebabkan penyakit menular di usia dewasa (Kemenkes, 2017).

Kejadian gizi kurang pada ibu hamil masih merupakan fokus perhatian Indonesia, masalah tersebut antara lain anemia dan ibu hamil kekurangan energi kronis (KEK). Riskesdas 2013 menunjukkan prevalensi risiko KEK pada ibu hamil (15-49 tahun) sebesar 24,2\%, khususnya prevalensi tertinggi ditemukan pada usia remaja (15-19 tahun) sebesar 38,5\% dibandingkan dengan kelompok lebih tua (20-24 tahun) sebesar 30,1\%. Proporsi ibu hamil dengan tingkat kecukupan energi kurang dari $70 \%$ angka kecukupan energi (AKE) sedikit lebih tinggi di pedesaan dibandingkan dengan perkotaan yaitu sebesar 52,9\% dibandingkan dengan 51,5\% (SDT, 2014). Sementara proporsi ibu hamil dengan tingkat kecukupan protein kurang dari $80 \%$ angka kecukupan protein (AKP) juga lebih tinggi di pedesaan dibandingkan dengan perkotaan yaitu sebesar 55,7\% dibandingkan 49,6\% (Kemenkes, 2017).

Perlu adanya deteksi dini dalam kehamilan yang dapat memantau pertumbuhan janin dan kesehatan bagi ibu selama hamil. Status gizi ibu selama kehamilan merupakan faktor penentu penting untuk pertumbuhan dan perkembangan janin di dalam kandungan (Syari, 2015). Antenatal Care (ANC) adalah salah satu upaya pencegahan awal dari faktor risiko kehamilan seperti KEK dan anemia. Menurut Organisasi Kesehatan Dunia (WHO) Antenatal care untuk mendeteksi dini terjadinya risikotinggi terhadap kehamilan dan persalinan juga dapat menurunkan angka kematian ibu dan memantaukeadaan janin. Perawatan antenatal umumnya dianggap metode yang efektif untuk meningkatkan hasilkehamilan, tetapi efektivitas spesifik program perawatan antenatal sebagai sarana untuk mengurangi kematian bayi dalam kelompok sosio-ekonomi kurang beruntung dan rentan perempuan belum di evaluasi secara mendalam (Mardiatun, 2015). Program kesehatan ibu dan anak merupakan salah satu program pokok di puskesmas yang mendapat prioritas tinggi, mengingat kelompok ibu hamil, menyusui, bayi, dan anak merupakan kelompok yang sangat rentan terhadap kesakitan dan kematian (Mardiatun, 2015). Di Indonesia, dosis suplemen zat besi (Fe-Folat) yang diberikan adalah sebesar $60 \mathrm{mg}$ besi elemental dan $0,25 \mathrm{mg}$ asam folat per hari atau 1 butir tablet tambah darah

(TTD) melalui 
kegiatan ANC (Depkes RI, 1995) dan pemerintah berencana untuk meningkatkan kandungan asam folat pada suplemen tersebut sehingga menjadi $60 \mathrm{mg}$ besi elemental dan $0,4 \mathrm{mg}$ asam folat dalam 1 butir TTD (Fitri, 2015).

Pelaksanaan Antenatal Care (ANC) telah dilakukan di UPT Karangjati, Ngawi, sebagai salah satu upaya menjaga kesehatan ibu hamil di desa Rejuno kecamatan Karangjati yang selama ini angka kejadian KEK dan anemia yang tinggi dengan nama program PATTEH PADUKA BERISTRI untuk pendampingan minum tablet tambah darah (TTD) oleh keluaga bagi ibu hamil berisiko tinggi.

Banyak penelitian membahas pentingnya zat gizi yang dibutuhkan oleh ibu hamil maupun tentang gangguan kesehatan ibu hamil yang disebabkan karena kekurangan zat-zat gizi yang dibutuhkan. Penelitian ini merupakan analisis lebih lanjut mengenai keefektifan program Antenatal Care (ANC) yang dicanangkan oleh WHO dan diaplikasikan di seluruh puskesmas di Indonesia sebagai pencegah gangguan kesehatan ibu hamil seperti KEK dan anemia.

\section{METODE}

Metode yang digunakan dalam penelitian ini adalah metode kualitatif. Penelitian kualitatif adalah penelitian yang dilakukan pada kondisi objek yang alami, peneliti sebagai instrumen kunci, teknik pengumpulan data dilakukan secara gabungan, data yang dihasil kan bersifat deskriptif, analisis data di lakukan secara induktif, dan penelitian ini lebih menekankan makna daripada generalisasi (Sedarmayanti dan Hidayat, 2011: 33).

Pengambilan data primer dilakukan dengan wawancara kepada Kepala UPT Karangjati, Ngawi, dr. HeriNurfahrudin, M.Kes pada hari Sabtu, 22 Juni 2019 dan pemberian data penunjang penelitian dari KepalaUPT Karangjati kepada peneliti.

\section{HASIL DAN PEMBAHASAN}

1. Jenis ibu hamil berisiko tinggi desa Rejuno Kecamatan Karangjati (Grafik 1)

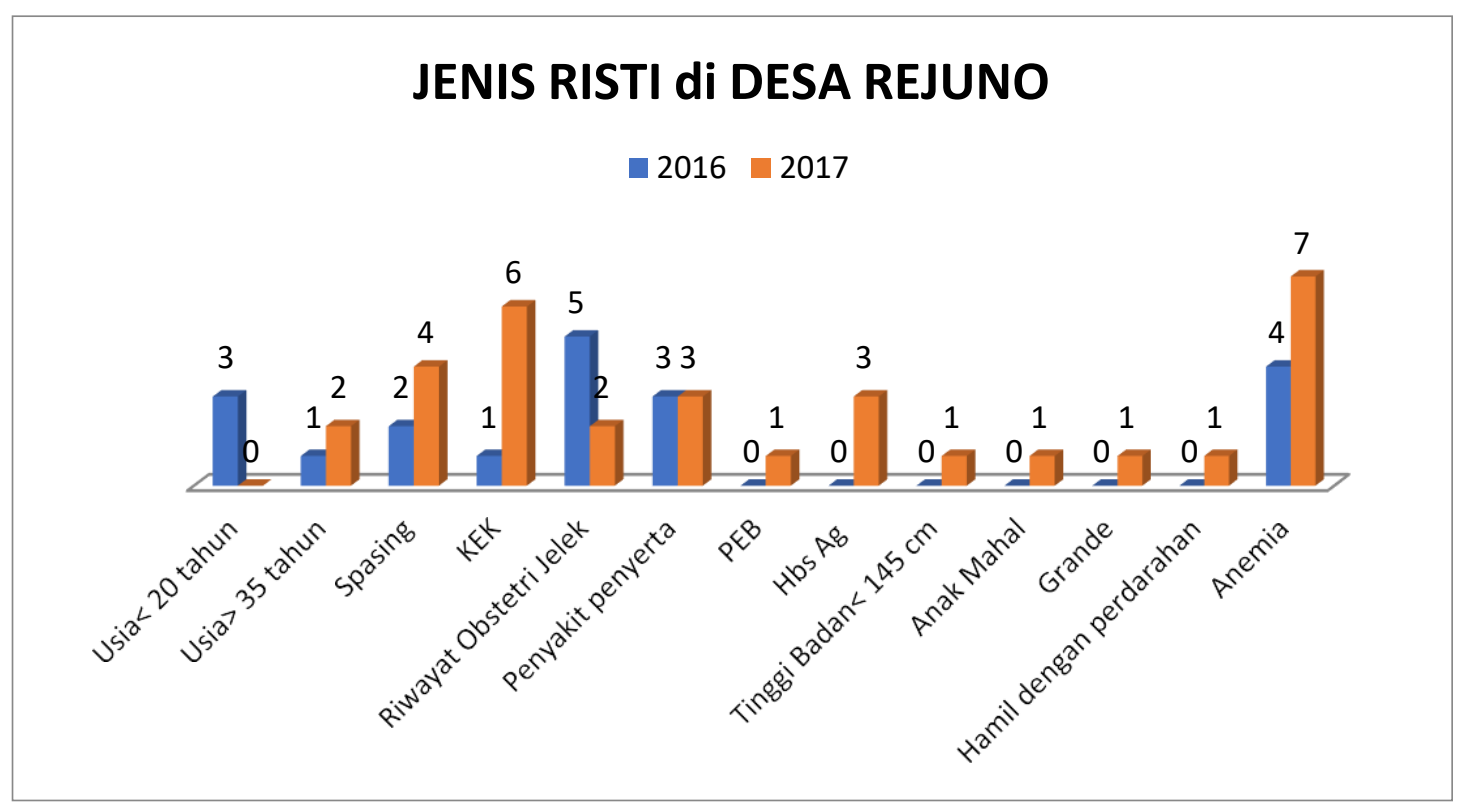


Grafik 1. (Risti: Risiko Tinggi) Angka ibu hamil berisiko tinggi jenis anemia dan KEK termasuk tinggi pada tahun 2017 dibanding jenis risiko tinggi lainnya.

2. Data ibu hamil berisiko tinggi se-kecamatan Karangjati 2017 (Grafik 2)

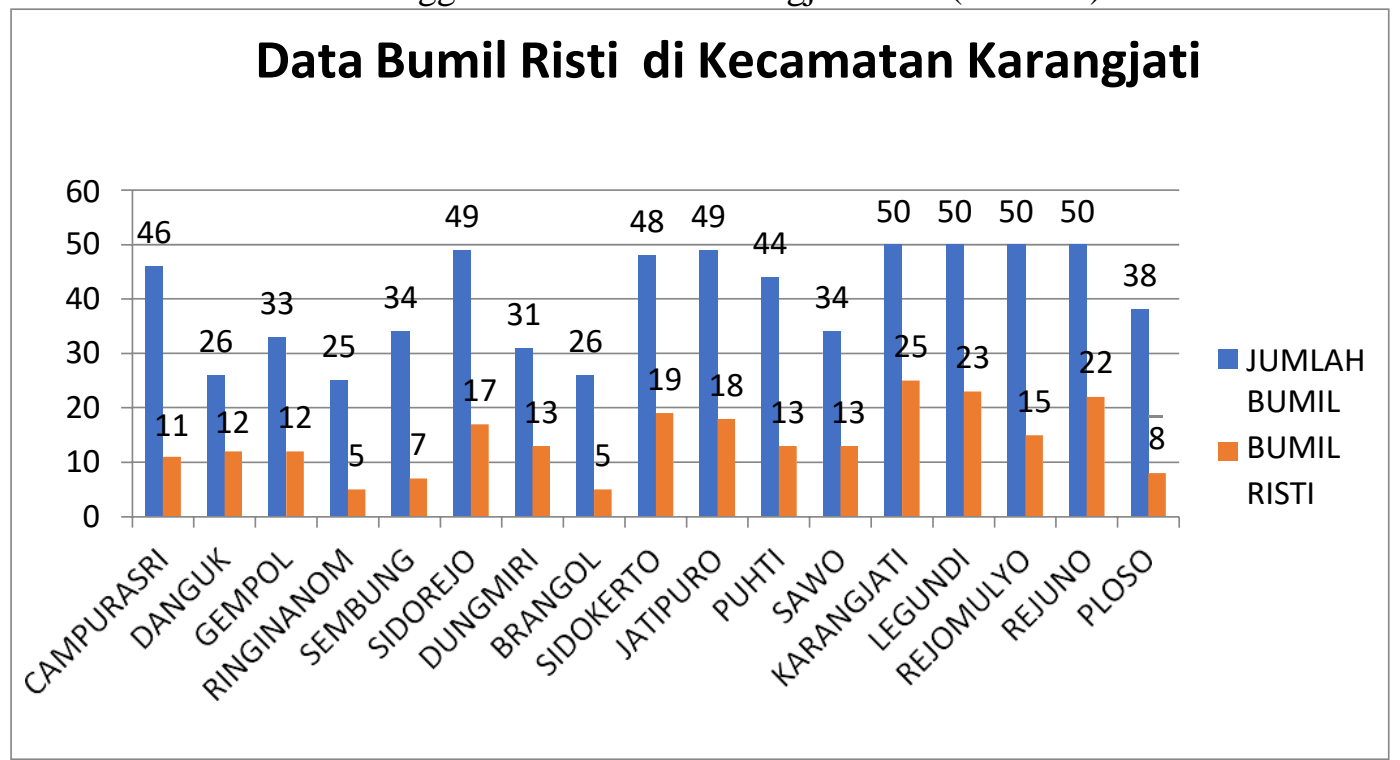

Grafik 2. (Bumil: Ibu hamil; Risti: Risiko Tinggi). Data di desa Rejuno, Kecamatan Karangjati, menunjukkan jumlah ibu hamil sebesar 50 dan jumlah ibu hamil berisiko tinggi sebesar 22. Terdapat sekitar 1 dari 2 ibu hamil di desa Rejuno, Kecamatan Karangjati yang termasuk ke dalam kategori risiko tinggi.

3. Data grafik nilai pretest dan posttest pengetahuan ibu hamil yang mengikuti program pendampingan sejenis antenatal care yaitu Patteh Paduka Beristri di kecamatan Karangjati (Grafik 3)

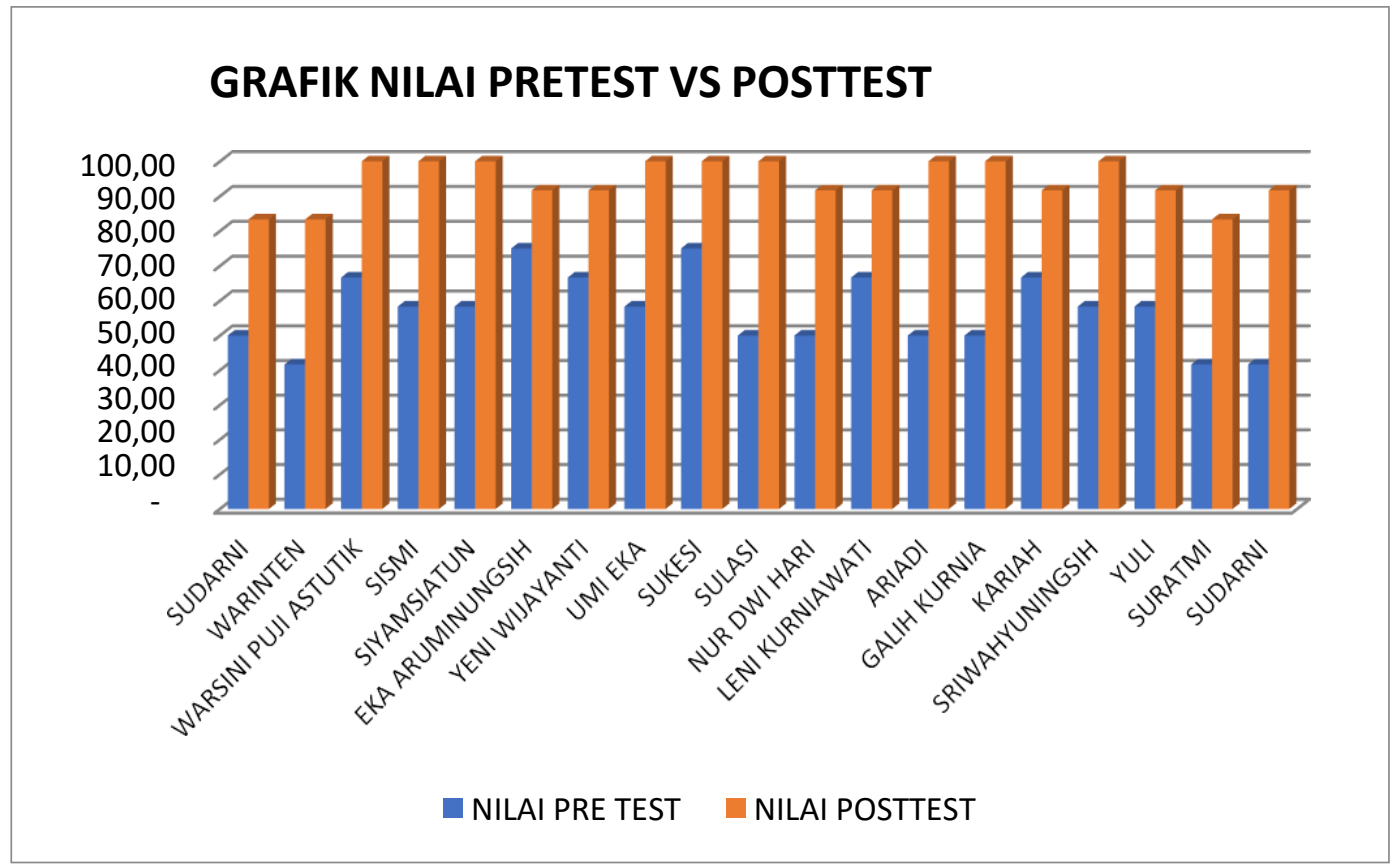

Grafik 3. Terdapat peningkatan pengetahuan ibu hamil dari sebelum (pre) hingga setelah (post) dilakukan pendampingan program Patteh Paduka Beristri. 


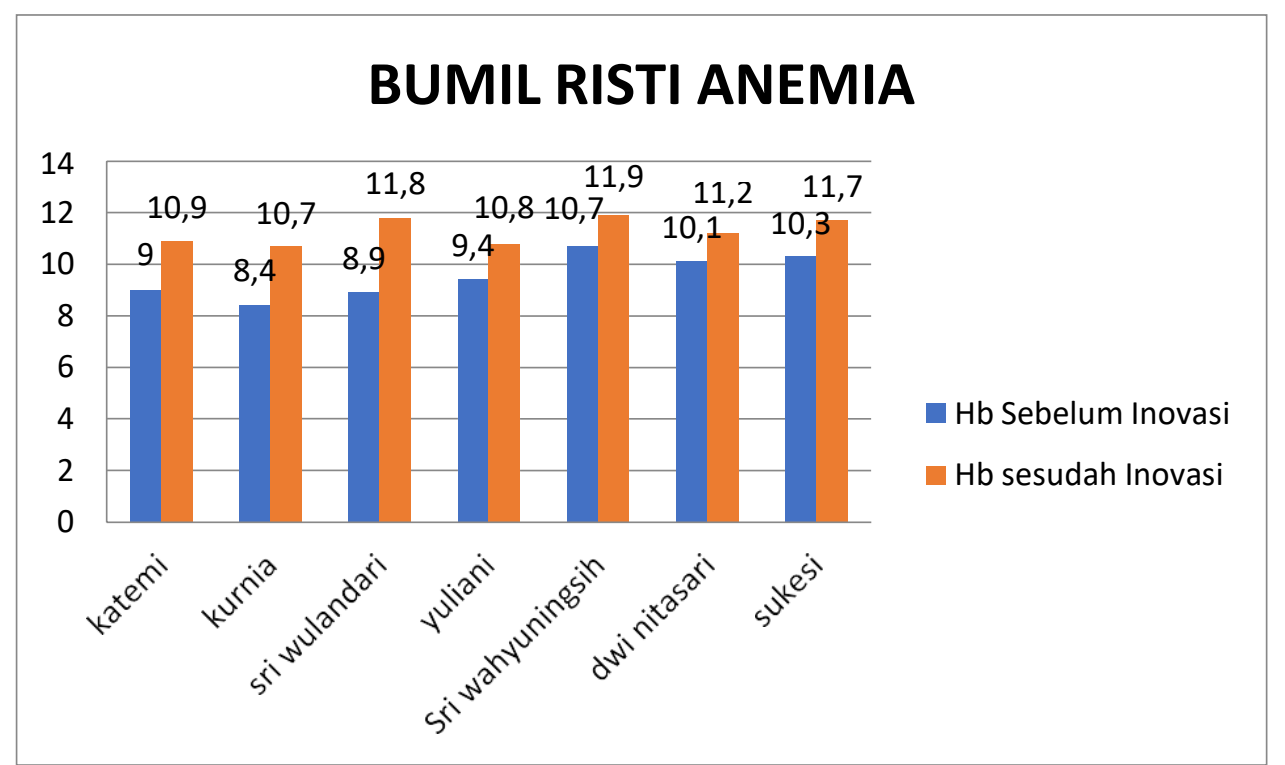

Grafik 4. Terdapat kenaikan $\mathrm{Hb}$ pada ibu hamil berisiko tinggi setelah mengikuti program Patteh Paduka Beristri.

Berdasarkan data yang diperoleh peneliti dari Kepala Puskesmas Kecamatan Karangjati, sebelum diadakannya inovasi Patteh Paduka Beristri yang merupakan adaptasi pelaksanaan Antenatal Care (ANC), angka KEK (kekurangan energi kronis) dan anemia pada ibu-ibu hamil di desa Rejuno Kecamatan Karangjati cukup tinggi berdasarkan Grafik 1. Merupakan sebuah ancaman bagi kesehatan ibu dan anak bila selama kehamilan ibu mengalami KEK dan anemia, kekurangan zat-zat gizi yang dibutuhkan dapat mengarah pada peningkatan angka stunting anak di Indonesia. Menurut Kepala UPT Karangjati, dr. Heri Nurfahrudin, M.Kes, program Patteh Paduka Beristri sebagai salah satu pemberdayaan masyarakat dengan pendampingan kepada keluarga ibu hamil agar meningkatkan rutinitas ibu hamil mengonsumsi tablet tambah darah (TTD). Termasuk upaya Antenatal care yang bertujuan untuk menjaga gizi ibu hamil dengan salah satu komponen zat gizi yang sangat dibutuhkan ibu yaitu Fe-Folat. Program dilakukan secara rutin dengan berbagai upaya dimulai dari pengumpulan data ibu hamil berisiko tinggi, advokasi dengan camat (kepala kecamatan), sosialisasi kader kesehatan, meningkatkan pengetahuan ibu hamil tentang gizi yang dibutuhkan terutama Fe-Folat (TTD), pendampingan langsung dari kader ke keluarga, dan melalui grup Whatsapp untuk mengingatkan disiplin minum TTD. Disebutkan bahwa setelah program Patteh Paduka Beristri oleh UPT Karangjati dilaksanakan, angka KEK dan anemia ibu hamil bisa menurun, terdapat peningkatan pengetahuan ibu hamil terhadap kehamilan berisiko tinggi dan angka $\mathrm{Hb}$ setelah program inovasi meningkat secara signifikan (berdasarkan Grafik 4). Hal ini menunjukkan bahwa program inovasi Patteh Paduka Beristri yang dilaksanakan berdasarkan Antenatal Care anjuran WHO, yang salah satu langkah nya adalah pemberian suplemen Fe-Folat (TTD-tablet tambah darah) efektif dalam menurunkan angka anemia dan KEK pada ibu hamil.

\section{SIMPULAN}

Setelah dilakukan pendekatan analisis isi dapat disimpulkan bahwa Antenatal Care dan pemberian suplemen Fe-Folat/TTD pada ibu hamil melalui program Patteh Paduka Beristri dari UPT Karangjati berjalan sangat efektif dalam menurunkan angka KEK (Kekurangan Energi Kronis) dan anemia pada ibu hamil di kecamatan Karangjati. Antenatal care melalui pendampingan keluarga langsung dari kader akan meningkatkan kepatuhan ibu hamil untuk meminum suplemen Fe-Folat (TTD), selain itu dapat meningkatkan pengetahuan ibu hamil tentang gizi yang dibutuhkan selama masa kehamilan dan apa saja gangguan yang akan terjadi ketika tidak menjaga gizi dengan baik. Pemantauan dengan programANC dari UPT Karangjati telah terbukti efektif didukung dari hasil laboratorium bahwa kasus anemia ibu hamil di Kecamatan Karangjati terutama desa Rejuno menurun, sekaligus menurunkan angka KEK yang juga dapat menurunkan probabilitas angka anak stunting di masyarakat. 


\section{SARAN}

Pelaksanaan Antenatal care melalui pendampingan langsung kader ke keluarga memudahkan pemantauan kepatuhan ibu hamil meminum suplemen Fe-Folat. Peran keluarga dalam pendampingan ibu hamil harus ditingkatkan. Peran lintas sektor dan lintas program di puskesmas harus lebih ditingkatkan. Kegiatan inovasi seperti Patteh Paduka Beristri sebagai upaya Antenatal care berjalan dengan baik diterapkan di desa lain.

\section{DAFTAR PUSTAKA}

\section{Jurnal}

Besuni, A., Jafar, N., Indriasari, R. (2013). Nutrients Intake Relationship Forming Red Blood Cells with Hemoglobin Levels in Pregnant Women in Gowa. Fakultas Kesehatan Masyarakat Universitas Hasanuddin Makassar, 000, 1-10.

Fitri, Y. P., Briawan, D., Tanziha, I., \& Amalia, L. (2015). Kepatuhan konsumsi suplemen besi dan pengaruhnya terhadap kejadian anemia pada ibu hamil di kota tangerang (. Fakultas Ekologi Manusia (FEMA), Institut Pertanian Bogor, 10(November), 171-178.

Mardiatun, Yani, L. A., Purnamawati, D., Zulkifli, \& Ristrini. (2015). Hubungan Riwayat Antenatal Care (ANC) dan Tingkat di Provinsi Nusa Tenggara Barat dan di Daerah Istimewa Yogyakarta (Analisis Lanjut Data Riset Kesehatan Dasar 2013), 221- 228.

Setyawati, B. (2013). Perbedaan Asupan Protein, Zat Besi, Asam Folat, Anemia dan Tidak Anemia di Puskesmas Tanggungharjo Kabupaten Grobogan. Fakultas Kedokteran Universitas Diponegoro.

Stephen, G., Mgongo, M., Hashim, T. H., Katanga, J., Stray-pedersen, B., \& Msuya, S. E. (2018). Anaemia in Pregnancy: Prevalence, Risk Factors, and Adverse Perinatal Outcomes in Northern Tanzania, 2018. https://doi.org/1846280

Syari, M., Serudji, J., \& Mariati, U. (2015). Artikel Penelitian Peran Asupan Zat Gizi Makronutrien Ibu Hamil terhadap Berat Badan Lahir Bayi di Kota Padang, 4(3), 729736. Retrieved from http://jurnal.fk.unand.ac.id.

\section{Buku}

Dinas Kesehatan Kabupaten Ngawi 2017. (2016). Profil Kesehatan Kabupaten Ngawi. Ngawi: Dinas Kesehatan Kabupaten Ngawi.

Kementerian Kesehatan Indonesia. (2017). Laporan Kinerja Ditjen Kesehatan Masyarakat Tahun 2016. Jakarta: Direktorat Jenderal Kesehatan Masyarakat Kementerian Kesehatan Tahun 2017. 


\section{Lampiran 1}

Narasumber: dr. Heri Nurfahrudin, M.Kes (Kepala UPT Karangjati)

Waktu: Sabtu, 22 Juni 2019

Pertanyaan Wawancara:

1. Apakah Antenatal Care sudah dijalankan dengan baik di Puskesmas Karangjati?

Jawaban: Program antenatal care dijalankan dengan baik disini tapi dengan penerapan atau inovasi yang berbeda karena fokus kita lebih untuk ibu hamil risiko tinggi, nama program nya Patteh PadukaBeristri, namun untuk ANC yang regular tetap di jalankan di Puskesmas seperti biasa agar Kartu Ibu dan Anak tetap aktif.

2. Apakah ibu hamil yang terdata di Puskesmas Karangjati rutin menjalankan Antenatal Care? Jawaban: Ya, semua ibu hamil yang terdata menjalankan ANC, dari tiap desa kami punya datanya, yang $\mathrm{Hb}$ nya rendah ada, intinya yang berisiko tinggi nama-nama ibu hamilnya kami punya.

3. Jumlah pasien ibu hamil KEK sekarang? Jawaban: Jumlah ibu hamil ada banyak bisa dilihat di Grafik 2 data yang saya berikan.

4. Jumlah pasien ibu hamil KEK sebelum ANC berjalan rutin?

Jawaban: Alhamdulillah semua ibu hamil yang terdata rutin menjalankan ANC.

5. Jumlah pasien ibu hamil anemia sekarang?

Jawaban: Jumlah nya bisa lihat di data ibu hamil Hb rendah "sebelum inovasi" yang saya berikan di Grafik 4.

6. Jumlah pasien ibu hamil anemia sebelum pemberian suplemen Fe-Folat rutin?

Jawaban: Jumlah nya bisa lihat di data ibu hamil $\mathrm{Hb}$ rendah "setelah inovasi" yang saya berikan diGrafik 4.

7. Suplemen Fe-Folat rutin diberikan pada pasien ibu hamil yang melakukan ANC?

Jawaban: Ya, diberikan rutin sesuai dengan tujuan program kami untuk mengingatkan ibu hamil di kecamatan Karangjati meminum TTD (tablet tambah darah) melalui kader yang telah di tentukan dan mengingatkan ibu-ibu melalui grup Whatsapp.

8. Bagaimana angka kejadian KEK (kekurangan energi kronis) ibu hamil sebelum dan sesudah antenatal care digalakkan pada ibu hamil di Kecamatan Karangjati, apakah ANC berjalan efektif menurunkan angka ibu hamil KEK?

Jawaban: Angka kejadian KEK tentunya berkurang ya, pastinya sesuai dengan tujuan ANC dan program Patteh Paduka Beristri kami Alhamdulillah berhasil menurunkan angka KEK.

9. Bagaimana angka kejadian ibu hamil anemia sebelum dan sesudah pemberian suplemen fefolat secara rutin saat antenatal care berlangsung, apakah pemberian suplemen Fe-Folat untuk ibu hamil efektif menurunkan angka ibu hamil anemia?

Jawaban: Sama jawabannya seperti pertanyaan sebelumnya dan bisa dilihat di Grafik 4 data yang saya berikan, angka ibu hamil anemia menurun. 